\title{
Prioritization of social capital indicators using extent analysis method
}

\author{
Nguyen Le Hoang Thuy To Quyen ${ }^{1}$, Phong Thanh Nguyen ${ }^{1,2, *}$, Vy Dang Bich Huynh ${ }^{1}$ \\ ${ }^{1}$ Ho Chi Minh City Open University (HCMCOU), Ho Chi Minh City, Vietnam \\ ${ }^{2}$ Construction Engineering and Management Division, ISE School, Chulalongkorn University (CU), Bangkok, Thailand
}

\section{ARTICLE INFO}

\section{Article history:}

Received 4 May 2017

Received in revised form

8 August 2017

Accepted 14 August 2017

\section{Keywords:}

Decision making

Fuzzy analytic hierarchy process

Extend analysis method

Social capital

\begin{abstract}
A B S T R A C T
This paper introduces Chang's extent analysis method approach for prioritizing Vietnam's social capital indicators. Using fuzzy AHP approach helps determine more efficiently importance of social capital indicators, especially deal with imprecise and uncertain human comparison judgments. In the proposed model, six dimensions of social capital are distinguished including bridging, bridging-link, bonding, bonding-link, particular trust and general trust. The results showed that general trust and particular trust nearly contribute the same important weights but the bonding and bondinglink share lesser weights than bridging and bridging-link.
\end{abstract}

(C) 2017 The Authors. Published by IASE. This is an open access article under the CC BY-NC-ND license (http://creativecommons.org/licenses/by-nc-nd/4.0/).

\section{Introduction}

Social capital has consistently been considered as a network resource by the researchers' community. It is found as an important driver for individual and community outcomes besides other traditional resources (natural, social economic and human resource capital). The findings of previous empirical studies have confirmed its benefit, especially to the poor (Grootaert et al., 2004). In Vietnam, social capital outcomes have become an interest of various interdisciplinary researchers since early 2000. However, the empirical findings were challenged due to the difficulty in social capital measurement (Uphoff and Wijayaratna, 2000). As a consequence of a multi-dimension concept, a consent definition of social capital is still debatable. Moreover, the impacts of different types of social capital are not the same (Granovetter, 1995). According to Krishna and Uphoff (2002), wellreflected social capital indicators in Italy may become inappropriate for other countries owning to its contextual characteristics.

Though the integrated index of social capital has been constructed in the literature review, its components' weights are contextually dependent (Van and Schmeets, 2013). As a consequence, these results cannot be generalized for the application in other nations. Therefore, it is essential to have

\footnotetext{
* Corresponding Author.

Email Address: phong.nt@ou.edu.vn (P. T. Nguyen) https://doi.org/10.21833/ijaas.2017.010.009

2313-626X/C 2017 The Authors. Published by IASE.

This is an open access article under the CC BY-NC-ND license

(http://creativecommons.org/licenses/by-nc-nd/4.0/)
}

empirical weights of the social capital index in Vietnam.

\section{Research background}

According to Hanifan (1916), the word "capital" in "social capital" does not refer to real assets. It implies values such as friendship, tolerance and good attitude towards the network's members. When the network is connected, social capital accumulation occurs. It will bring positive externality to the individual and the community. In the definition, Hanifan (1916) implicitly indicates two features of social capital which are widely accepted as capital characteristics: i) accumulation and ii) future return. Moreover, Bourdieu (1986) has explained above definition when clarifying network by defining a structure of more or less institutionalized relationships. The network is necessary but not sufficient for creating social capital. Coleman (1988) has added to the definition with the emphasis on trust and shared norms and networks which can drive the coordination actions in the society. Putnam et al. (1994) have emphasized that shared norms are fostered by the trust. In summary, a social capital principle with the composition of trust and network has got a wide consensus in research communities (Van and Schmeets, 2013).

As a multidimensional construct, personal social capital is measured through the hierarchical model with two key components: networks (structural) and trust (cognitive). Structural dimension is approached as an individual network based on resource. The potential network based resource (Narayan, 2002) accessed by individual depend on person' tie strength and social standing with the network 
members. Tie strength is a factor to distinguish bonding and bridging while social standing is for linking (Szreter and Woolcock, 2004). Bonding refers to strong ties such as kinship, neighborhood. This is characterized by the horizontal link between those with the same demographic and socioeconomic status (Nguyen et al., 2016). Wagner et al. (2014) has added to the argument with its deep connection. In conclusion, this is a closed network with informal ties, focusing on homogeneous group identity (Putnam, 2000). On the contrary, bridging extends the link to other groups at similar financial position and power. It refers to weak ties with formal structure. This network is useful in approaching the outside resources.

In general, bonding can enhance the consolidation within a closed network but it may, without bridging, derive the narrow interest and the consequence is outsiders' exclusion. The same philosophy is applied for linking. A strong linking may benefit the favored groups by accessing to rich funding or less strict regulations, which is potential for corruption. Therefore, the combination of social standing with bonding and bridging to form bonding-link and bridging-link besides a traditional way of analyzing social capital as bonding, bridging, and linking is an innovative way. The calculation of social capital indicators' weights in the integrated index based on this new philosophy is desirable for policy recommendation on using this resource.

\section{Research methodology}

The Analytical Hierarchy Process (AHP), introduced by Saaty (2005) was known as a set of multi-attribute decision analysis (MADA) methods (Quyen et al., 2017). However, experts or decisionmakers usually find that it is more confident to give interval judgments than fixed value judgments (Tran, 2017; Kabir and Sumi, 2015; Vavan and Braike, 2015). This is because usually he/she is unable to explicit about his/her preferences due to the fuzzy nature of the comparison process (Nguyen et al., 2017). The Chang (1996) extent analysis method is the easiest FAHP approach in fuzzy AHP methods. The steps of Chang (1996) extent analysis approach are as follows (Zhu et al., 1999):

Let

$X=\left\{x_{1}, x_{2}, \ldots, x_{n}\right\}$

be an object set, and

$G=\left\{g_{1}, g_{2}, \ldots, g_{m}\right\}$

be a goal set.

According to the method of Chang's (1996) extent analysis, each object is taken and extent analysis for each goal, $g_{i}$, is performed, respectively. Therefore, $m$ extent analysis values for each $i^{\text {th }}$ object for $m$ goals can be obtained, with the following signs:

$\widetilde{M_{g_{l}}^{J}}\left(M_{g_{i}}^{1}, M_{g_{i}}^{2}, \ldots, M_{g_{i}}^{m}\right)$
All extent analysis values $\widetilde{M_{g_{l}}^{j}}(i=1,2, \ldots, n ; j=1$, $2, \ldots, m)$ are triangular fuzzy numbers (TFNs).

Step 1: The value of fuzzy synthetic extent with respect to the $i^{\text {th }}$ object is defined as:

$\widetilde{S_{l}}=\sum_{j=1}^{m} \widetilde{M_{g_{l}}^{J}} \otimes\left[\sum_{i=1}^{n} \sum_{j=1}^{m} \widetilde{M_{g_{l}}^{J}}\right]^{-1}$

to obtain $\sum_{j=1}^{m} \widetilde{M_{g_{l}}^{J}}$, we perform the fuzzy addition operation of $m$ extent analysis values for a particular matrix such that

$\sum_{j=1}^{m} \widetilde{M_{g_{l}}^{j}}=\left(\sum_{j=1}^{m} l_{j}, \sum_{j=1}^{m} m_{j}, \sum_{j=1}^{m} u_{j}\right)$

and to obtain $\left[\sum_{i=1}^{n} \sum_{j=1}^{m} \widetilde{M}_{g_{l}}^{j}\right]^{-1}$, we perform the fuzzy addition operation of $\widetilde{M_{g_{l}}^{j}}$ values such that

$\sum_{i=1}^{n} \sum_{j=1}^{m} \widetilde{M_{g_{l}}^{\jmath}}=\left(\sum_{i=1}^{n} l_{i}, \sum_{i=1}^{n} m_{i}, \sum_{i=1}^{n} u_{i}\right)$

with $i=1,2, \ldots, n ; j=1,2, \ldots, m$; and then compute the inverse of the vector in above equation such that

$\left[\sum_{i=1}^{n} \sum_{j=1}^{m} \widetilde{M_{g_{l}}^{\jmath}}\right]^{-1}=\left(\frac{1}{\sum_{i=1}^{n} u_{i}}, \frac{1}{\sum_{i=1}^{n} m_{i}}, \frac{1}{\sum_{i=1}^{n} l_{i}}\right) ;$

therefore,

$S_{i}=\left(\sum_{j=1}^{m} l_{j}, \sum_{j=1}^{m} m_{j}, \sum_{j=1}^{m} u_{j}\right) \otimes\left(\frac{1}{\sum_{i=1}^{n} u_{i}}, \frac{1}{\sum_{i=1}^{n} m_{i}}, \frac{1}{\sum_{i=1}^{n} l_{i}}\right)$.

Step 2: The degree of possibility of

$\widetilde{M_{2}}=\left(l_{2}, m_{2}, u_{2}\right) \geq \widetilde{M_{1}}=\left(l_{1}, m_{1}, u_{1}\right)$

is defined as following

$V\left(\widetilde{M_{2}} \geq \widetilde{M_{1}}\right)$

and can be equivalently expressed as follows:

$V\left(\widetilde{M_{2}} \geq \widetilde{M_{1}}\right)=\mu_{\widetilde{M_{2}}}(d)$
$=\left\{\begin{array}{c}1 \text { if } m_{2} \geq m_{1} \\ 0 \text { if } l_{1} \geq u_{2} \\ \frac{l_{1}-u_{2}}{\left(m_{2}-u_{2}\right)-\left(m_{1}-u_{1}\right)} \text { otherwise }\end{array}\right.$

where $d$ is the ordinate of the highest intersection point $D$ between two fuzzy number, $\mu_{\widetilde{M}_{1}}$ and $\mu_{\widetilde{M_{2}}}$ (Fig. 1). To compare $\widetilde{M_{1}}$ and $\widetilde{M_{2}}$, we need both the values of $V\left(\widetilde{M_{1}} \geq \widetilde{M_{2}}\right.$ ) and $V\left(\widetilde{M_{2}} \geq \widetilde{M_{1}}\right.$ ) (Al-Ahmari, 2008).

Step 3: The degree possibility for a convex fuzzy number to be greater than $k$ convex fuzzy numbers $\widetilde{M}_{\iota}(i=1,2, \ldots, k)$ can be defined by

$V\left(\widetilde{M} \geq \widetilde{M_{1}}, \widetilde{M_{2}}, \ldots, \widetilde{M_{k}}\right)$

$=V\left[\left(\widetilde{M} \geq \widetilde{M_{1}}\right)\right.$ and $\left(\widetilde{M} \geq \widetilde{M_{12}}\right)$ and $\ldots$ and $(\widetilde{M} \geq$

$\left.\left.\widetilde{M_{k}}\right)\right]=\min V\left(\widetilde{M} \geq \widetilde{M_{l}}\right), i=1,2, \ldots, k$

Assume that:

$d^{\prime}\left(A_{i}=\min V\left(\widetilde{M_{l}} \geq \widetilde{M_{k}}\right)\right.$ for $k=1,2, \ldots, n ; k \neq i$

then the weight vector is given by

$W^{\prime}=\left[d^{\prime}\left(A_{1}\right), d^{\prime}\left(A_{2}\right), \ldots, d^{\prime}\left(A_{n}\right)\right]^{T}$ 
where $A_{i}(i=1,2, \ldots, n)$ are $n$ elements.

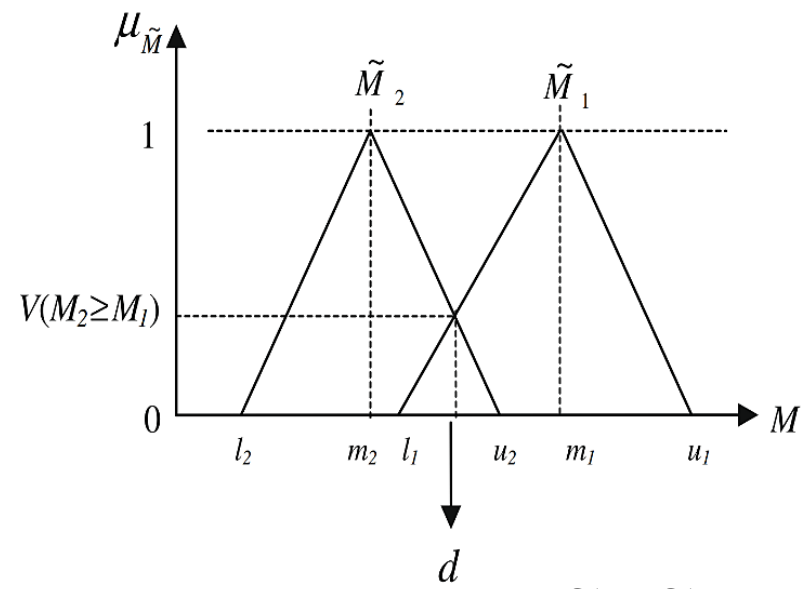

Fig. 1: The intersection between $\widetilde{M_{1}}$ and $\widetilde{M_{2}}$

Step 4: After normalization, the normalized weight vectors are

$W=\left[d\left(A_{1}\right), d\left(A_{2}\right), \ldots, d\left(A_{n}\right)\right]^{T}$

where $W$ is a nonfuzzy number.

\section{Result and discussion}

In the social capital index (Table 1), the results showed that the trust shares $58,5 \%$ while the network is $41,5 \%$. Particular and general trusts are equally important in the experts' view. Addition, we can see that the weight of bridging-link is the largest (0.534) in the network and the bridging is the second (0.2918). The bonding and bonding-link share lesser weights than bridging and bridging-link. They got the weights of 0.1070 and 0.0671 respectively. The findings proposed values which refer for social capital appraisal in Vietnam country.

Table 1: Table of weight coefficients

\begin{tabular}{|c|c|c|c|c|}
\hline Objective & Element & Weight & Sub-element & Weight \\
\hline \multirow{6}{*}{$\begin{array}{l}\text { Social } \\
\text { Capital } \\
\text { Index }\end{array}$} & \multirow{4}{*}{$\begin{array}{l}\text { Network } \\
\text { (C1) }\end{array}$} & \multirow{4}{*}{0.415} & $\begin{array}{l}\text { Bonding } \\
\text { (C11) }\end{array}$ & 0.107 \\
\hline & & & $\begin{array}{l}\text { Bonding-link } \\
\text { (C12) }\end{array}$ & 0.0671 \\
\hline & & & $\begin{array}{l}\text { Bridging } \\
\text { (C13) }\end{array}$ & 0.2918 \\
\hline & & & $\begin{array}{l}\text { Bridging-link } \\
\text { (C14) }\end{array}$ & 0.534 \\
\hline & \multirow{2}{*}{ Trust (C2) } & \multirow{2}{*}{$\begin{array}{l}\text { Trust } \\
0.585\end{array}$} & $\begin{array}{l}\text { Particular } \\
\text { trust (C21) }\end{array}$ & 0.5 \\
\hline & & & $\begin{array}{l}\text { General trust } \\
\text { (C22) }\end{array}$ & 0.5 \\
\hline
\end{tabular}

\section{Conclusion}

This paper proposes a quantitative approach to priority social capital index in Vietnam using extent analysis method (EAM) method based on fuzzy AHP. The results showed that trust is more important than the network. This reflects the priority in nurturing trust for the Vietnamese. In addition, the research results confirm the importance of bridging and bridging-link compared to bonding and bondinglink. This implies the necessity of fostering the open network, especially when it combines with social standing because it is useful for leveraging the resources in the community.

\section{Acknowledgment}

The authors gratefully acknowledge Ho Chi Minh City Open University (HCMCOU), Vietnam and Chulalongkorn University, Thailand for partial supporting this research.

\section{References}

Al-Ahmari A (2008). A methodology for selection and evaluation of advanced manufacturing technologies. International Journal of Computer Integrated Manufacturing, 21(7): 778789.

Bourdieu P (1986). The forms of capital. In: Richardson JG (Ed.), Handbook of theory and research for the sociology of education: 241-258. Greenwood Publishing Group, New York, USA.

Chang DY (1996). Applications of the extent analysis method on fuzzy AHP. European Journal of Operational Research, 95(3): 649-655.

Coleman JS (1988). Social capital in the creation of human capital. American Journal of Sociology, 94: S95-S120.

Granovetter M (1995). Getting a job: A study of contacts and careers. University of Chicago Press, Chicago, USA.

Grootaert C, Narayan D, Jones VN, and Woolcock M (2004). Measuring social capital: an integrated questionnaire. World Bank Working Paper, No. 18. World Bank Publications, Washington DC, USA.

Hanifan LJ (1916). The rural school community center. Annals of the American Academy of Political and Social Science, 67(1): 130-138.

Kabir G and Sumi RS (2015). Hazardous waste transportation firm selection using fuzzy analytic hierarchy and PROMETHEE methods. International Journal of Shipping and Transport Logistics, 7(2): 115-136.

Krishna A and Uphoff $\mathrm{N}$ (2002). Mapping and measuring social capital through assessment of collective action to conserve and develop watersheds in Rajasthan, India. In: Grootaert C and van Bastelaer $\mathrm{T}$ (Eds.), The role of social capital in development: An empirical assessment: 85-124. Cambridge University Press, Cambridge, UK.

Narayan D (2002). Social capital and economic development: wellbeing in developing countries. Edward Elgar, Northampton, USA.

Nguyen TP, Phuc NV, and Quyen NLHTT (2017). Application of fuzzy analytic network process and TOPSIS method for material supplier selection. Key Engineering Materials, 728: 411-415.

Nguyen VP, Nguyen PT, Thuy QLH, Nguyen T, and Huynh VDB (2016). Calculating weights of social capital index using analytic hierarchy process. International Journal of Economics and Financial Issues, 6(3): 1189-1193.

Putnam RD (2000). Bowling alone: America's declining social capital. Journal of Democracy, 6(1): 65-78. 
Putnam RD, Leonardi R, and Nanetti RY (1994). Making democracy work: Civic traditions in modern Italy. Princeton University Press, Princeton, USA.

Quyen NLHTTQ, Nguyen PT, and Huynh VDB (2017). A hybrid multi criteria decision analysis for engineering project manager evaluation. International Journal of Advanced and Applied Sciences, 4(4): 49-52.

Saaty TL (2005). Making and validating complex decisions with the AHP/ANP. Journal of Systems Science and Systems Engineering, 14(1): 1-36.

Szreter S and Woolcock M (2004). Health by association? Social capital, social theory, and the political economy of public health. International Journal of Epidemiology, 33(4): 650-667.

Tran TT (2017). An empirical research on selecting the targeted suppliers and purchasing process of supermarket. International Journal of Advanced and Applied Sciences, 4(4): 96-109.
Uphoff $\mathrm{N}$ and Wijayaratna CM (2000). Demonstrated benefits from social capital: the productivity of farmer organizations in Gal Oya, Sri Lanka. World Development, 28(11): 1875-1890.

Van BJ and Schmeets H (2013). Developing a social capital index for the Netherlands. Social Indicators Research, 113(3): 859886.

Vavan Z and Braike S (2015). Data envelopment analysis for weight control strategies. International Journal of Advanced and Applied Sciences, 2(1): 22-24.

Wagner HT, Beimborn D, and Weitzel T (2014). How social capital among information technology and business units drives operational alignment and IT business value. Journal of Management Information Systems, 31(1): 241-272.

Zhu KJ, Jing Y, and Chang DY (1999). A discussion on extent analysis method and applications of fuzzy AHP. European Journal of Operational Research, 116(2): 450-456. 